\title{
IN VITRO MULTIPLICATION OF Gmelina arborea Roxb. ADULT TREES
}

\section{MULTIPLICACIÓN IN VITRO DE ÁRBOLES ADULTOS DE Gmelina arborea Roxb.}

\begin{abstract}
Isidro E. Suárez ${ }^{1}$, Claudia C. Acosta ${ }^{2}$, Kellen C. Gatti ${ }^{3}$
${ }^{1}$ Ingeniero Agrónomo Ph.D., Profesor Departamento de Ingeniería Agronómica y Desarrollo Rural, Universidad de Córdoba, Carrera 6 No. 76-103, Montería - Colombia. Email: iesuarez@correo.unicordoba.edu.co; ${ }^{2}$ Ingeniera Biotecnóloga M.Sc. Biotecnología Vegetal, Departamento de Ingeniería Agronómica y Desarrollo Rural, Universidad de Córdoba, Carrera 6 No. 76-103, Montería - Colombia. ${ }^{3}$ Ing. Forestal, M.Sc. Departamento de Ingeniería Agronómica y Desarrollo Rural, Universidad de Córdoba, Carrera 6 No. 76-103, Montería - Colombia.
\end{abstract}

Rev. U.D.C.A Act. \& Div. Cient. 16(1): 97 - 102, 2013

\section{SUMMARY}

Melina (Gmelina arborea Roxb.) is a forest species with fast growing, tall trees. Melina propagation is based on cuttings isolated from juvenile seedlings. The present research focused on micropropagation of melina plants, grown from cuttings isolated from mature trees. Explants were surface disinfected with $\mathrm{NaOCl}(0.5 \%)$ and established on semisolid MS with (in $\mathrm{mg} \mathrm{L}^{-1}$ ) myo-inositol (100), sucrose (30.000) and TC-agar (7.000). The effect of BAP $(0 ; 0.44 ; 1.33$ and $2.22 \mu \mathrm{M})$ on shoot proliferation, AIB $(0,0.49,1.48$ and $2.46 \mu \mathrm{M})$ on in vitro rooting and substrate (sand and peat) on ex vitro survival were evaluated. Treatments were distributed with a complete randomized design, 20 replicates per treatment and 80 total experimental units were evaluated. Collected data showed that compared to control BAP increased shoot proliferation, shoot length and leaf number, while IBA induced higher root number, root length and rooting percentages. Higher survival rates were observed when plants were transferred to peat.

Key word: BAP, forest tree, in vitro rooting, micropropagation.

\section{RESUMEN}

Melina (Gmelina arborea Roxb.) es una especie forestal de gran potencial por la rapidez de crecimiento y altura de sus árboles; sin embargo, la propagación clonal para siembra de huertos forestales se basa preferencialmente en el enraizamiento de estacas provenientes de plantas jóvenes obtenidas a partir de semillas. En el presente estudio se evaluó la micropropagación de plantas de melina obtenidas de miniestacas enraizadas aisladas de árboles adultos. Los explantes fueron desinfectados con $0,5 \% \mathrm{NaOCl}$ y establecidos en medio MS semisólido con (en $\mathrm{mg} \mathrm{L}^{-1}$ ) mio-inositol (100), sacarosa (30.000) y agar (7.000). Se evaluó el efecto de BAP $(0 ; 0,44 ; 1,33$ y 2,22 $\mu \mathrm{M})$ sobre la multiplicación de brotes, el efecto de $\operatorname{AIB}(0 ; 0,49 ; 1,48$ y $2,46 \mu \mathrm{M}$ ) sobre el enraizamiento de tallos micropropagados y el del tipo de sustrato (arena y turba) sobre la adaptación ex vitro de las plantas micropropagadas. Todos los tratamientos se distribuyeron con un DCA y cada tratamiento se repitió 20 veces para un total de 80 unidades experimentales. Los resultados mostraron que el suministro de BAP en el medio incrementa significativamente la tasa de multiplicación, la longitud de brotes y el número de hojas producidas, mientras que la adición de AIB aumenta el porcentaje de enraizamiento e influye significativamente en las variables número de raíces por tallo y longitud promedio de raíz. La mayor supervivencia se observó en el sustrato turba.

Palabras clave: BAP, enraizamiento in vitro, forestal, micropropagación.

\section{INTRODUCTION}

Melina (Gmelina arborea Roxb.) is a Lamiaceae species native to Southeast Asia and distributed through Pakistan, Cambodia, India, Sri Lanka and South China. In South America, melina was introduced into Costa Rica, Brasil, Venzuela, Trinidad, Cuba Belice and Colombia where is well adapted and commercially cultivated mostly in the Northern Coast. The rapid tree growth (up to $30 \mathrm{~m}$ in $8-10$ years) and trunk diameter makes this plant species suitable for forestry, wood production, energy and $\mathrm{CO}_{2}$ capture (Onyekwelu, 2004; Dvorak, 2004; Wang, 2004; Roshetko et al. 2004; Morales, 2004; USDA, 2013). Additionally, the plant tolerance to adverse soil conditions such as low $\mathrm{pH}$, low nutrient and tropical rainforest climate has contributed 
to position melina as the fourth largest forest tree crop in the Colombian Caribbean Coastal area (Murillo et al. 2011).

Melina can be propagated by seeds and cuttings, usually from juvenile seedlings. However, both sources result in high plant variability which affects crop management and productivity (Lauridsen \& Kjaer, 2002; Gatti et al. 2011). Commonly, industrial management of forest plantations depends on large quantities of high quality uniform plant material for planting and crop rotation; in Cordoba, melina crops area is expected to increase at least three folds in the next few years (FORCARIBE, 2010). Therefore, micropropagation based on explants isolated from adult trees is an alternative for genetic stability, size uniformity, plant quality and a continuous source of plants for new crops (Nguyen \& Kozai, 2001).

Melina micropropagation has been previously reported (Kannan \& Jasrai, 1996; Gamboa \& Abdelnour, 1999). However, results are based on the use of juvenile explants from in vitro and ex vitro germinated seedlings. In the present research, clonal propagation of $G$. arborea was achieved by inducing in vitro proliferation of explants with axillary meristems isolated from selected adult trees.

\section{MATERIALS Y METHODS}

Mother plants were grown from cuttings isolated from eight-year old plants (Clones 12010 y 12019) planted at the Forest For Future (3F) field (Tierralta-Córdoba, Colombia $8^{\circ} 47^{\prime} 11^{\prime \prime}$ LN / 7551'26" LO) by January 2010. The cuttings were rooted and maintained in a shade house with $60 \%$ light penetration, $30^{\circ} \mathrm{C}$, foggy mist and weekly sprays with benzoimidazole $\left(2 \mathrm{~g} \mathrm{~L}^{-1}\right)$, cupper oxychloride $\left(2 \mathrm{~g} \mathrm{~L}^{-1}\right)$ and Nutrifoliar ${ }^{\circledR}\left(3 \mathrm{~mL} \mathrm{~L}^{-1}\right)$, on the leaves. Explants consisted of $2-3 \mathrm{~cm}$-stem sections with axillary shoots, rinsed with distilled water added with $\operatorname{Extran}^{\oplus}(0.1 \%)$, benzoimidazole $(0.15 \%)$ during $5 \mathrm{~min}$., followed by an instant methanol (70\%) immersion and thereafter surface-disinfected with a $\mathrm{NaOCl}$ $(0.5 \%)$ solution for $15 \mathrm{~min}$, followed by three rinses with sterile distilled water. Surface-disinfected explants were established in semisolid establishment medium (EM) consisting of MS (Murashige \& Skoog, 1962) with (in $\mathrm{mg} \mathrm{L}^{-1}$ ) myo-inositol (100), sucrose (30.000) and TC-agar (7.000), with four-week transfers to fresh medium with the same formulation.

In vitro established explants were cultured in EM independently supplied with different $(0.0,0.44,1.33$ and $2.22 \mu \mathrm{M})$ benzilaminopurine (BAP) levels to evaluate explant proliferation. A single $2-3 \mathrm{~cm}$ shoot was transferred into a $250 \mathrm{cc}$ glass flask containing $30 \mathrm{~mL}$ of EM. Flasks were covered with heavy duty aluminum foil, sealed with Parafilm ${ }^{\circledR}$ and stored at $20^{\circ} \mathrm{C}$ with 12 hour photoperiod using cool-white fluorescent lamps $\left(40 \mu \mathrm{mol} \mathrm{m}^{-2} \mathrm{~s}^{-1}\right)$. Treatments were repeated 20 times for a total of 80 experimental units distributed using a complete randomized design. After four weeks of culture, data for number of new shoots per explant, leaf number per explant and shoot length were registered.

In vitro proliferated shoots were individually transferred onto EM independently supplied with different $(0.0,0.49,1.48$ and $2.46 \mu \mathrm{M}$ ) indole-3-butyric acid (IBA) concentrations to evaluate the effect on in vitro shoot rooting. Cultures were stored as indicated for the shoot proliferation stage. After four weeks of culture, the number of rooted shoots, roots per shoot and root length were registered. In vitro rooted shoots and in vitro proliferated, non-rooted, shoots were transferred to either sand or peat substrate, placed inside a shade house with $50 \%$ light penetrations and foggy mist for 2 min every hour. Shoots were planted in 48 cell plastic trays filled with the respective substrate. A single shoot was placed per cell and a 144 total number of shoots were evaluated for each treatment. After six weeks, the number of ex vitro-adapted plants was registered.

All media $\mathrm{pH}$ was adjusted to $5.7-5.8$ previous to agar addition. Media were sterilized in autoclave at $121^{\circ} \mathrm{C}$ and $1.1 \mathrm{kgcm}^{-2}$. Data were analyzed with an ANOVA and means separated with a Tukey test $(\alpha=0.05)$ based on the statistical model $Y_{i j k}=\mu+a_{i}+b_{j+} a b_{i j}+C_{i j k}$; where $\mu$ was the mean, $i$ the clones, $j$ the PGR levels and $C$ the experimental error.

\section{RESULTS AND DISCUSSION}

New shoots emerged from axillary meristems present in the original explants, although a callus growth at the basal end of the explants was observed; no shoots grew from the callus tissue (Figure 1). The analysis of variance showed significant differences $(\operatorname{Pr}<0,005)$ among treatments with respect to the number of new shoots per explant, leaf number and shoot length. The general data indicated that shoots cultured in medium supplemented with BAP at $2.22 \mu \mathrm{M}$ produced the highest multiplication rate, more leaves per shoot and longer shoots for both clones. In contrast explants cultured without BAP showed the lowest values for the same variables (Table 1). Additionally, clone 12019 showed a better performance in terms of number of shoots per explant and shoot length than clone 12010 at the highest BAP level, indicating a possible genotype-associated effect.

Micropropagation based on repeated axillary meristem elongation is possible by culturing explants with pre-existing meristems on high levels of cytokinin supplied media (Kane, 1996). Based on biological efficiency and costs, BAP is probably the most used cytokinin for micropropagation of forest species, a group of plants with recalcitrance for tissue culture purposes. Several studies have shown the effects of cytokinin-supplied media on in vitro melina shoot multiplication: Gamboa \& Abdelnour (1999) reported a 
Table 1. Effect of different BAP level on Gmelina arborea Robx. shoot multiplication

\begin{tabular}{|c|c|c|c|c|c|c|}
\hline \multicolumn{7}{|c|}{ CLONES } \\
\hline \multirow[b]{2}{*}{ BAP $(\mu M)$} & \multicolumn{3}{|c|}{12010} & \multicolumn{3}{|c|}{12019} \\
\hline & $\begin{array}{c}\text { Shoots per } \\
\text { explant }\end{array}$ & $\begin{array}{c}\text { Shoot length } \\
(\mathrm{cm})\end{array}$ & Leaf number & $\begin{array}{c}\text { Shoots per } \\
\text { explant }\end{array}$ & $\begin{array}{l}\text { Shoot lenght } \\
(\mathrm{cm})\end{array}$ & Leaf number \\
\hline 0.00 & $0.0 \mathrm{a}$ & $0.0 \mathrm{a}$ & $0.0 \mathrm{a}$ & $0.0 \mathrm{a}$ & $0.0 \mathrm{a}$ & $0.0 \mathrm{a}$ \\
\hline 0.44 & $0.41 \mathrm{~b}$ & $2.11 \mathrm{~b}$ & $6.13 \mathrm{~b}$ & $1.54 \mathrm{~b}$ & $2.48 \mathrm{~b}$ & $8.77 \mathrm{~b}$ \\
\hline 1.33 & $0.57 \mathrm{c}$ & $2.12 \mathrm{~b}$ & $6.62 \mathrm{~b}$ & $1.63 \mathrm{~b}$ & $2.82 \mathrm{c}$ & $10.19 \mathrm{c}$ \\
\hline 2.22 & $1.10 \mathrm{~d}$ & $2.36 \mathrm{c}$ & $10.59 \mathrm{~d}$ & $2.37 \mathrm{c}$ & $3.71 \mathrm{~d}$ & $11.30 \mathrm{~d}$ \\
\hline
\end{tabular}

Numbers with the same letter are not different according to Tukey $(\alpha=0.05)$.
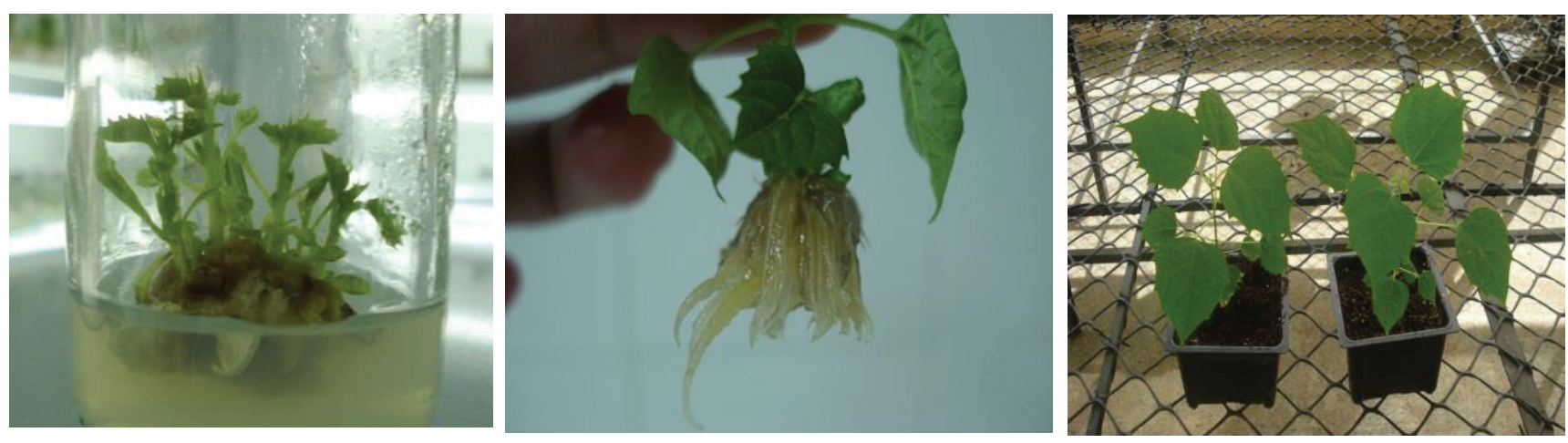

Figure 1. Shoot multiplication, in vitro rooting and ex vitro adapatation of Gmelina arborea Robx. micropropagated plants.

2.41 new shoot formation from explants with pre-existing meristems, isolated from in vitro germinated plants, cultured in $2.46 \mu \mathrm{M}$ BAP supplied MS semisolid medium. Kannan \& Jasrai (1996), using plant material from similar origin and similar BAP supply, reported a four shoot per explant multiplication rate. In the present research, explants consisted of rejuvenated shoots originally isolated from adult plants, which allows to knowing the phenotypic characteristics of the tree in contrast to randomly using juvenile plants as explant source.

Studies conducted on tropical forest species, others than melina, show micropropagation responses similar to the results observed in the present study. Castro et al. (2002) reported a 2.1 new shoots per explant of teak (Tectona grandis) cultured on semiolid MS with $2.22 \mu$ M BAP. Daquinta et al. (2001) observed a maximum of 2.6 new shoots from teak explants isolated from adult trees cultured on semisolid MS simultaneously supplied with $4.44 \mu \mathrm{M}$ BAP and $1.83 \mu \mathrm{M}$ kinetin, while Suárez et al. (2006) reported 2.5 new shoots from explants isolated from four-year old Tabebuia rosea plants cultured on semisolid MS supplied with $17.76 \mu \mathrm{M}$ BAP. Although, the present study elucidate the way to in vitro propagate melina plants from explants isolated from mature trees, multiplication rates are still low therefore research to improve the protocol efficiency should be continued.

The data presented in this results showed that in addition to the significant increase on the shoot multiplication rate, the BAP medium supply significantly $(\operatorname{Pr}<0.005)$ increases shoot length and number of leaves per explant compared to the control treatment as well (Table 1). This performance is particularly important, based on the fact that in vitro cultured plants are photosynthetically inactive (Kane, 1996); therefore, an increase in the number and size of organs (leaves and shoots) are important to accumulate energetic reserves. Since photosynthetic competence is low during transfer to ex vitro conditions, reserves accumulated on organs are used to fulfill plant functioning needs until new photosynthetically active leaves are formed and roots are capable of nutrient adsorption. 
Adventitious roots from micropropagated shoots of all rooting treatments emerged from the basal end of the shoots (Figure 1). Rooting percentage increased accordingly with AIB supply in the medium. Shoots cultured in absence of IBA had the lowest rooting percentage (22\%) while those cultured with $\geq 1.48 \mu$ M IBA showed $80-100 \%$ root formation (Table1).

The ANOVA results indicated that IBA addition to the medium significantly $(\operatorname{Pr}<0.05)$ increases the root number per shoot and root length per shoot in both, 12010 and 12019, clones (Table 2). Roots per shoot increased $>10 \mathrm{x}$ in shoots cultured with $2.46 \mu \mathrm{M}$ IBA compared to those without IBA while root length was three times longer in IBA treated shoots compared to control cultured shoots. Rooting performance was statistically similar for both clones (Table 2).

In vitro rooting is promoted by exogenous auxin supply on the culture medium. Root development is intended to provide a water and nutrient uptake mechanism when in vitro cultured plants are transferred to ex vitro conditions (Kane, 1996). Previous melina rooting studies show close-related data with the present study. Sen et al. (1992) and Kannan \& Jasrai

Table 2. Effect of different IBA levels on in vitro Gmelina arborea Robx. shoot rooting.

\begin{tabular}{|c|c|c|c|c|c|c|}
\hline \multicolumn{7}{|c|}{ CLONES } \\
\hline AIB $(\mu M)$ & $\begin{array}{c}\text { Rooting } \\
(\%)\end{array}$ & $\begin{array}{c}\text { Root number } \\
\text { per shoot }\end{array}$ & $\begin{array}{c}\text { Root length } \\
(\mathbf{c m})\end{array}$ & $\begin{array}{c}\text { Rooting } \\
(\%)\end{array}$ & $\begin{array}{c}\text { Root number } \\
\text { per shoot }\end{array}$ & $\begin{array}{c}\text { Root length } \\
(\mathbf{c m})\end{array}$ \\
\hline 0.00 & 22 & $0.33 \mathrm{a}$ & $0.22 \mathrm{ac}$ & 30 & $0.50 \mathrm{a}$ & $0.72 \mathrm{a}$ \\
\hline 0.49 & 60 & $2.40 \mathrm{~b}$ & $1.34 \mathrm{~b}$ & 40 & $2.00 \mathrm{a}$ & $0.75 \mathrm{a}$ \\
\hline 1.48 & 100 & $12.71 \mathrm{c}$ & $2.48 \mathrm{c}$ & 80 & $11.20 \mathrm{~b}$ & $2.05 \mathrm{~b}$ \\
\hline 2.46 & 100 & $13.10 \mathrm{c}$ & $3.30 \mathrm{~d}$ & 100 & $14.00 \mathrm{~b}$ & $3.74 \mathrm{c}$ \\
\hline
\end{tabular}

Numbers with the same letter are not different according to Tukey $(\alpha=0.05)$.

(1996) reported $80 \%$ shoot rooting with a 4,9 $\mu$ M IBA supply on semisolid 1/2MS. Gamboa \& Abdelnour (1999) reported $<50 \%$ rooting percentage in melina micropropagated shoots cultured on different semisolid MS salt concentrations media with no auxin supply.

Micropropagated shoots from both clones showed a higher survival rate when transferred onto peat (c12010 $=90 \%$; c12019 $=80 \%$ ) rather than those transferred onto sand (c12010=35\%; c12019=25\%). The propagation substrate provides anchorage, and supply water and nutrients to the growing plant. Water retention is probably the most important factor during ex vitro plant adaptation since permanent water is necessary for cell multiplication and differentiation during rhizogenesis (Marks et al. 2002). As a result of particle size, sand does not have water retention but provides drainage; in contrast, peat has $>80$ water retention and additionally provides air exchange (Walczak et al. 2002). Water supply is critical for callus formation (cell division) and root emission, while oxygen is required for root respiration and growth of the rooting structure; peat guarantee both elements in a more consistently way than sand does (Sturion, 1981; Paiva, 2000).

The low functionality of in vitro grown roots and auxin supply costs are concerns that makes necessary to look for alternatives to avoid in vitro rooting. The collected data showed that melina is probably an easy rooting species with more than $20 \%$ rooting percentage, even in explants cultured without IBA supply, due to probably high levels of endogen auxin synthesis (Hartmann et al. 2000). Despite the efficient response of micropropagated melina shoots to IBA for in vitro root development, both in vitro rooted and nonrooted shoots showed similar survival rates after six weeks of culture on ex vitro conditions ( $>70 \%$ on peat and $<40 \%$ on sand). These results may indicate that in vitro rooting may not be necessary to obtain high survival rates on ex vitro transferred micropropagated melina shoots; this possibility can additionally help to reduce costs and time for plant production.

A protocol for G. arborea plant micropropagation has been developed using rejuvenated explants from adult trees which increases uniformity of plant material for establishing new crops allowing technical management of crop activities, reduces loses from seed-borne diseases and facilitates handling a deliveries of large amounts of plant material. Significant increases in shoot multiplication rates due to BAP supplied media were observed letting to 
potentially produce miles of plants from a single explant in a year-round multiplication cycle using a $2.22 \mu \mathrm{M}$ in the multiplication medium and ex vitro adaptation using peat as substrate; however, studies to improve multiplication rates are necessary. Although rooting was positively increased by culturing micropropagated shoots on IBA supplied media, ex vitro adaptation of micropropagated non-rooted in vitro shoots is possible.

Aknowledgements: The authors would like to express their gratitude to the following for their support: Universidad de Córdoba, Cadena Forestal de Córdoba (FORCARIBE), 3F-Kanguroid and Ministerio de Agricultura y Desarrollo Rural de Colombia - Project No. 021-2007k7104-35207. Conflict of interest: The manuscript was prepared and reviewed with the participation of all the authors, who declare that no conflict of interest exists, that jeopardizes the validity of the results presented.

\section{BIBLIOGRAPHY}

1. CASTRO, D.; DÍAZ, J.; LINERO, J. 2002. Propagación in vitro de árboles élite de teca (Tectona grandis L.). Rev. Col. Biotecn. 1:49-53.

2. DAQUINTA, M.; RAMOS, L.; RODRÍGUEZ, R.; ESCALONA, M. 2001. Algunos elementos en la micropropagación de la teca. Biotecn. Vegetal (Cuba) 1:39-44.

3. DVORAK, W. 2004. World view of Gmelina arborea: opportunities and challenges. New Forests (The Netherlands). 28(2-3):111-126.

4. GAMBOA, J.P.; ABDELNOUR, A. 1999. Micropropagación de melina (Gmelina arborea ROXB). Agr. Costarricense 23(1):69-76.

5. FORCARIBE (CADENA FORESTAL DE CÓRDOBA). Acuerdo Regional de Competitividad para la Cadena Forestal en el departamento de Córdoba, Colombia. CONIF (Colombia), 14p.

6. GATTI, K.; SUÁREZ, I.; ESPITIA, M.; TOBAR, D. 2011. Producción de Plántulas Forestales de Tectona grandis Linn F., Acacia mangium Willd y Gmelina arbórea Roxb. Universidad de Córdoba, Colombia, $77 \mathrm{p}$.

7. USDA. 2013. ARS National Genetic Resources Program. Germplasm Resources Information Network - (GRIN) [Online Database]. National Germplasm Resources Laboratory, Beltsville, Maryland(USA). URL: available through Internet in: http://www.ars-grin.gov/cgi-bin/ npgs/html/taxon.pl?17827 (accessed 14/02/2013)

8. HARTMANN, H.; KESTER, D.; DAVIES, J.; GENEVE, R. 1997. Plant Propagation, Principles and Practices. Prentice Hall Inc., Upper Saddle River (USA), 770p.

9. KANE, M. 1996. Micropropagation from Pre-existing Meristemos, En: Gray, D.; Trigiano, R, (Eds.) Plant Tissue Culture Concepts and Laboratory Excercises. CRC Press (USA), p.75-86.

10. KANNAN, V.; JASRAI, Y. 1996. Micropropagation of Gmelina arborea. Plant Cell, Tissue and Organ Culture (The Netherlands). 46:269-271.

11. LAURIDSEN. E.; KJAER, E. 2002. Provenance research in Gmelina arborea Roxb. A summary of results from three decades of research and discussion of how to use them. Int. Forestry Rev. (UK) 4(1):1-15.

12. MARKS, T.; FORD, Y.; CAMERON, R.; GOODWIN, C.; MYERS, P.; JUDD, H. 2002. A role for polar auxin transport in rhizogenesis. Plant Cell, Tissue and Organ Culture. 70(2):189-198.

13. MORALES, A. 2004. Potential of Gmelina arborea for solid wood products. New Forests. 28(2-3):293-297.

14. MURASHIGE, T.; SKOOG, F. 1962. A revised medium for rapid growth and bioassay with tobacco tissue culture. Physiol. Plant. (Finland) 15:473-497.

15. MURILLO, O.; ESPITIA, M.; CASTILLO, C. 2011. Fuentes Semilleras para la Producción Forestal. Universidad de Córdoba, (Colombia) Montería, 77p.

16. NGUYEN, Q.; KOZAI, T. 2001. Photoatotrophic micropropagation of tropical and subtropical woody plants. Progress Biotechn. (USA) 18:335-344.

17. ONYEKWELU, C. 2004. Obove-ground biomass production and biomass equations for even-aged Gmelina arbórea (ROXB) plantations en southwestern Nigeria. Biomass and Bioenergy (USA). 26(1):39-46.

18. PAIVA, H. 2000. Aspectos gerais da propagacao de plantas. UFV, Viçosa (Brasil). 632p.

19. ROSHETKO, J.M.; MULAWARMAN; PURNOMOSIDHI, P. 2004. Gmelina arbórea - a viable species for smallholder tree farming in Indonesia? New Forests. 28(2-3):207-215. 
20. SEN, J.; ISLAM, M.; ROY, S.; HADIUZZMAN, S. 1992. Micropropagation of juvenile and adult Gmelina arborea. Bangaldesh Assoc. Plant Tissue Culture \& Biotecn. 2(2):89-95.

21. STURION, J. 1981. Métodos de producao y técnicas de manejo que influenciam o padrao de qualidade de mudas de essencias florestais. EMBRAPA (Brasil) p.1-8.
22. SUÁREZ, I.; AVILA, M.; JARMA, A. 2006. Desarrollo de un protocolo para propagación in vitro de roble (Tabebuia rosea Bertol DC). Rev. Temas Agrarios (Colombia) 11(2):52-62.

23. WALCZAK, R.; ROVDAN, E.; WITKOWSKA-WALCZAC, B. 2002. Water retention characteristics of peat and sand mixtures. Int. Agrophys. (Poland). 16:161-165.

Received: 7 May 2012

Accepted: 27 February 2013 